\title{
The Echo of 'After-Poetry': Hans Bethge and the Chinese Lyric
}

\author{
BEN HUTCHINSON
}

\begin{abstract}
The publication, in 1908, of Hans Bethge's Die chinesische Flöte marked a highpoint in the reception of Chinese poetry in modern Europe. Bethge's 'Nachdichtungen' of poems from the Tang dynasty through to the late 1800s were extraordinarily popular, and were almost immediately immortalized by Gustav Mahler's decision to use (a selection from) them as the text for Das Lied von der Erde (1909). Yet Bethge could not read Chinese, and so based his poems on existing translations by figures including Judith Gautier, whose Livre de Jade had appeared in 1867. This article situates Bethge's reception of Chinese poetry - and in particular, that of Li-Tai-Po - within the context of European chinoiserie, notably by concentrating on his engagement with a recurring imagery of lyrics and Lieder. Although he was deaf to the music of Chinese, Bethge was extremely sensitive to the ways in which Li-Tai-Po's self-conscious reflections on poetic creation underlay his 'after-poems' or Nachdichtungen, deriving his impetus from images of the rebirth of prose - songs, birdsong, lyrics, Lieder - as poetry. The very form of the 'lyric' emerges as predicated on its function as echo: the call of the Chinese flute elicits the response of the European willow. That this is necessarily a comparative process - between Asia and Europe, between China, France, and Germany - suggests its resonance as an example of the West-Eastern lyric.
\end{abstract}

Few works of art in the early twentieth century can have been as 'comparative' in conception as Gustav Mahler's Das Lied von der Erde (1909). Poised halfway between symphony and song - the ageing composer did not want to label it a 'symphony' since he had already written eight previous symphonies, and so feared invoking the supposed 'curse of the ninth' - Mahler's music is based on poems taken from Hans Bethge's anthology Die chinesische Flöte (1907). Yet Bethge's poems are themselves based on Hans Heilmann's anthology Chinesische Lyrik (1905), which is in turn a German rendition of Judith Gautier's French Livre de Jade (1867), which are in turn translations of classical Chinese poetry. Mahler's masterpiece, in other words, crowns a comparative cultural chain of rare complexity. 
How are we to understand the links in this chain? In this article, I propose to focus on the words behind the music, or rather on the ways in which words themselves are understood as constituting music. Bethge's translations of Gautier's translations of Li-Tai-Po reflect not only the circulation of ancient Eastern forms of lyric within modern Western culture - or at least, of that which is perceived as 'Eastern' forms of lyric - but also more specifically a self-conscious, modernist emphasis on the status of the poem qua poem. By this I mean to suggest that the rhetorical status of the 'song' functions as a common concern of both Chinese poetry of the Tang dynasty and European poetry of the modernist period, and that the changing status of this song - whether played on the flute or plucked on the lyre, whether understood as Lied or as lyric - reflects the changing status of poetry. If comparative literature, to borrow Georg Brandes' celebrated metaphor, resembles a telescope - one end reduces, the other magnifies ${ }^{1}$ - then the genre of the 'lyric' functions in the manner of this telescope: by reducing our critical perspective to the reception and adaptation of lyric poetry, it magnifies the cultural continuity between widely disparate times and places. By foregrounding the changing, local aspects of literature, poetry as it is translated across the centuries also brings out the unchanging, universal aspects of literature. 'Afterpoems' - the German subtitle of Bethge's translations of Chinese lyric - insist on both similarity and difference.

What are the implications of such an intercontinental reading for the emergence of modernist modes of lyric? I would like to suggest that the comparative cultural chain discussed in this article provides an illuminating example of 'planetary modernism', to borrow the term coined by Susan Stanford Friedman. ${ }^{2}$ Stanford Friedman puts forward a number of quasi-synonyms for the 
methodology underlying this term - 'critical collage', 'cultural parataxis', 3 'paratactic juxtaposition' - all of which are intended to convey the processes by which periods and places very distant from one another can usefully be read alongside each other. My contention is that the interaction between the three poets discussed in this article, Li-Tai-Po, Gautier, and Bethge, functions as an instance of this critical 'collage' - not in the sense that I, as critic, am arbitrarily bringing them together, but in the sense that they situate themselves in a cultural continuum centred around the changing modes of the lyric. If 'paratactic juxtaposition', in Stanford Friedman's understanding of the term, enables 'meanings that become newly visible through reading separate things together', 4 then modernist European poetry - here through Gautier and Bethge, elsewhere through leading twentieth-century poets such as Brecht and Pound - gains new meaning when seen as an echo of Chinese Tang poetry.

Walter Cohen's magisterial History of European Literature (2017) suggests that the influence of Asian and Oriental forms of writing on their European counterparts has been seriously underestimated, ${ }^{5}$ and it is in the rhetorical categories of genre and style that this influence has arguably had greatest purchase. Certainly the development of the European lyric is unthinkable without its Asian antecedents: from the muwashshah in medieval Spain to the ghazal in the modern sonnet, examples abound of the vestigial presence of Arabic, Persian, and Chinese categories in Western poetry. ${ }^{6}$ Within the specifically German tradition, the association of song with the Orient - in opposition to the plastic arts of the Occident - emerged as a topos of Romanticism, which in turn informed the association of music with modernity. In his Vorschule der Ästhetik (1804), for instance, Jean Paul distinguishes between 'Greek or plastic poetry' and the new 
'romantic or musical' lyric, ${ }^{7}$ and the distinction echoes into Goethe's WestÖstlicher Divan, in which the word Lied appears forty-three times. ${ }^{8}$ In a poem pointedly entitled 'Lied und Gebilde' ('Song and Plastic Art'), Goethe typically contrasts Greek 'clay' with Oriental fluidity, culminating in the heavily stressed emergence of song as the result of Western engagement with the East: 'Löscht ich so der Seele Brand / Lied es wird erschallen' ('If the soul's hot brand be cooled / then song shall echo clear'). ${ }^{9}$ Goethe's self-image as translator of Hafiz anticipates Bethge's self-image as translator of Li-Tai-Po (and indeed of numerous other Oriental writers): the Eastern poet finds his Western 'after-poet'.

This tradition of seeing 'song' as rising in the East resonates, we will see, into Bethge's presentation of Chinese poetry. But it also resonates into the European idea of modernism more generally, torn as it is between the postEnlightenment discourse of reason on the one hand and the desire to flee into the supposedly exotic realms of pre-rational intuition on the other. The very term 'modernism' has undergone a dramatic revision in recent years, being extended as far back as the first millennium BCE: to paraphrase the opening words of Eric Hayot's contribution to the Oxford Handbook of Global Modernisms, what in the idea of 'European modernism' belongs to Europe, and what to modernism? Who, in short, owns modernism? ${ }^{10}$ Yet even when understood in the narrower, traditional sense as something like the period 1850-1950, Asian and Oriental influences were inescapably constitutive of the European modernist aesthetic. As Hayot notes, 'one of the signal features of the history of Anglo-European modernism was its unceasing and intense relation to China and Chinese literature, which was in turn but a subset of modernism's more general interest in East Asia, Africa, and the Orient'. ${ }^{11}$ Bertolt Brecht, Richard Dehmel, Ezra Pound, the 
Bloomsbury group: all these writers and more were directly inspired by (what they perceived as) Chinese aesthetics. What is equally striking, however, is how few of them could actually read their source material in its original form. Bethge's reception of classical Chinese poetry was entirely typical of his generation of poets: only once the professional Sinologist Judith Gautier had domesticated the unfamiliar Chinese lyrics into the familiar European form of French could he have any access to the Orient. From the perspective of literary criticism, this convoluted process of reception offers a rare opportunity to investigate the intercultural agency of the lyric. Does poetry get found in translation?

Bethge's access to the original poems was in fact more restricted even than this. The French versions of the Chinese poems - prepared by Théophile Gautier's daughter Judith in collaboration with the Marquis D'Hervey-Saint-Denys and subsequently disseminated in numerous 'orientalizing' editions (see figure 1) were first translated into German by Hans Heilmann, before being 'imitated' by Bethge in Die chinesische Flöte. If the term brings to mind, in the modern Western context, Robert Lowell's self-consciously loose Imitations (1961) of European modernists such as Baudelaire, Rilke, and Montale, Bethge's model is if anything more distant still, as indicated by his subtitle Nachdichtungen chinesischer Lyrik [After-poems of the Chinese Lyric]. The term 'after-poems' offers a more honest model of comparative reception than direct translation, since it brings out the tension between humility (the prefix nach implies a secondary status) and hubris (the noun Dichtung competes with the original Lyrik for precedence) that animates all acts of translation. Bethge wanted to be understood not only as a translator, in short, but also as a poet in his own right. 


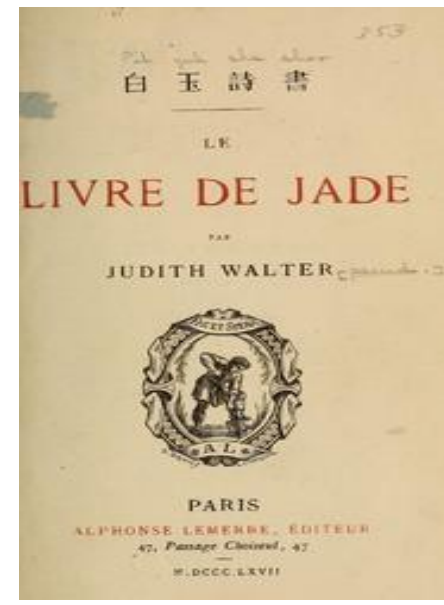

Such interpretative subtleties did little to diminish Bethge's success. Mahler's almost immediate adoption (and adaptation) of Bethge's 'translations', a mere year after their initial publication, testifies to their rapid reception within the German-speaking world. With an astonishing print run of some 100,000 copies, Bethge had clearly hit on a winning formula, one that his publishers Insel were only too happy to encourage. That Bethge would go on to make a lucrative career out of popularizing oriental poetry - producing, among other achievements, editions of Hafiz and Omar Khayyam, of Arabic, Egyptian, Turkish, Japanese, and Indian poetry - reflects the art nouveau enthusiasm for all things 'oriental' around the turn of the century. With its enchanting cover illustration by the influential book designer Emil Rudolf Weiss (see figure 2), Die chinesische Flöte functions as a kind of primer in this regard, an anthology of Chinese poetry that covers some three thousand years from the pre-Christian millennium (the dates are notably presented in this manner for a European audience) to the 1870s. We don't need to re-read Edward Said to see that a version of Orientalism is at work here in creating - and then marketing - a composite 'Chinese' tradition for the consumption of the West. 


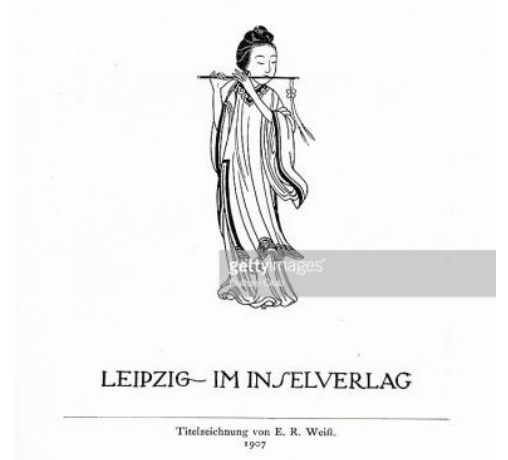

Figure 2: First edition of Die chinesische Flöte (1907)

Yet the noun in Bethge's title is just as important, I would argue, as the adjective. The eponymous flute functions as an Eastern variation on the Western tradition of the Orphic lyre, a Zauberflöte or magic flute evoking the Chinese tradition of singing, rather than merely reciting poems. Within the specific context of his anthology, Bethge's title is most directly inspired, it would seem, by Li-TaiPo's poem 'Die geheimnisvolle Flöte' [The mysterious flute]. The greatest poet of the Tang dynasty, Li-Tai-Po (701-762) ${ }^{12}$ is surrounded by legend, not the least of which is that he was always drunk and ultimately 'died of the moon' - which is to say, that he fell into a river while admiring the moon in its reflection (a banal fact that was transformed into the far more pleasing fiction of dolphins carrying him off into the skies). Ezra Pound - whom T. S. Eliot hailed, influentially if anachronistically, as 'the inventor of Chinese poetry for our time', and whose eradefining slogan 'make it new' was stolen, as Pound himself notes in Canto 53, from (the first king of the Shang dynasty) 'Tching [who] prayed on the mountain and / wrote MAKE IT NEW / on his bath tub'13 - includes a number of poems by Li-TaiPo in Cathay, so his importance to European modernism hardly needs emphasising. Given this status, it is perhaps no surprise that there are more poems 
by Li-Tai-Po in Bethge's collection than by anyone else (and indeed the majority of Mahler's text for Das Lied von der Erde ultimately derives from him). As such, we may fairly concentrate on Li-Tai-Po as the key exemplar of Bethge's approach, supplemented by occasional references to other poets of the era.

'Die geheimnisvolle Flöte' is typically brief and deceptively simple:

An einem Abend, da die Blumen dufteten

Und alle Blätter an den Bäumen, trug der

Wind mir

Das Lied einer entfernten Flöte zu. Da schnitt

Ich einen Weidenzweig vom Strauche, und

Mein Lied flog, Antwort gebend, durch die

blühende Nacht.

Seit jenem Abend hören, wann die Erde schläft,

Die Vögel ein Gespräch in ihrer Sprache. ${ }^{14}$
One evening, when flowers were wafting their scents

and all the leaves were on the trees, the wind brought to me the song of a far-off flute. Immediately I cut a branch from the willow, and my song flew to give answer through the blossoming night.

Since that evening, when the earth is asleep, the birds hear a conversation in their language.

Composed in the standard idiom of classical Chinese poetry - with its physical sense of trees and leaves, and its metaphysical sensibility of enigma and evanescence - Li-Tai-Po's poem is given fresh impetus through Bethge's voice. It is not just the details of translation that reanimate the poem, but also the very fact of translation. For the brief poem functions as a strikingly appropriate allegory of East-Western poetry: the wind carries the distant song of a flute to the poet; the poet responds by blowing on a twig of willow. Monologue becomes dialogue; passive distance becomes active presence. The indirect object of the poem ('mir') becomes the direct subject ('Da schnitt / Ich...'), with the action of twisting and 
cutting the twig enacted by the catch and release of the enjambment; out of this process emerges 'my poem' ('Mein Lied'), heavily stressed at the start of the final line of the main stanza, as the true song of the flute.

All of this originally relates, of course, to Li-Tai-Po himself. Within the context of a translation of a translation, Bethge's syntactical interventions bring out the dialogic nature of this intercontinental - and indeed inter-epochal conversation. The final two lines, standing in their own little stanza, call on the birds as witnesses to this crepuscular conversation, strikingly inverting the usual association of birds with song: the birds are listening, not singing. The nightingales, now, are the poet and - in my reading - the translator. Yet something stranger still seems to have happened in the transition from the first to the second stanzas, for the birds now hear the song in their own language. The dialogue between flute and willow, in short, has been translated into birdsong.

The poem thus offers a kind of mise-en-abîme of the whole process of translating poetry (especially once one takes into account its quasi-titular status). If we consider this from the point of view of the translator it becomes more interesting still, since Bethge's German idiom betrays unmistakable traces of the translator's own cultural context. The 'Blätter' of the second line, for instance, can be read, in the manner of Bethge's contemporaries Stefan George or Rainer Maria Rilke, as indicating the 'leaves' of both a tree and a book; the wind thus becomes a quasi-angelic voice filling the poet with inspired breath, in the manner of Rilke's much-mythologized claim to have heard the opening of the first Duino Elegy whispered to him by the wind. More intriguing still is what would seem to be a passing echo, in the phrasing of the closing couplet, of the recently rediscovered Friedrich Hölderlin (Norbert von Hellingrath was at this point working on his 
epochal edition that would be published in 1913). The famous lines from Hölderlin's poem 'Friedensfeier' [Celebration of Peace] run as follows:

\author{
Viel hat von Morgen an, \\ Seit ein Gespräch wir sind und \\ hören voneinander, \\ Erfahren der Mensch; bald sind wir \\ aber Gesang. 15
}

\author{
Man has learned much since \\ morning, \\ For we are a conversation, and we \\ can listen \\ To one another. Soon we'll be song.
}

Read alongside the closing lines of Li-Tai-Po's poem - 'Seit jenem Abend hören, wann die Erde schläft, / Die Vögel ein Gespräch in ihrer Sprache' - the echo of Hölderlin would seem to suggest that Bethge is translating Li-Tai-Po not only linguistically, but also conceptually (in what one might describe as a modernist, allusive manner). Hölderlin's morning is Li-Tai-Po's evening; Hölderlin's humanist conversation is Li-Tai-Po's interspecies song. For Hölderlin, too, the humans are becoming song - they are just not quite there yet. It is as though, in mobilizing Hölderlin's verses (if only in the reader's subconscious), Bethge is evoking everything that Man has indeed learned ('erfahren') since the time of Li-Tai-Po in the 'Morgenland'.

Another way of saying this is that Die chinesische Flöte is an anthology about poetry as well as of poetry. Poetology, that is to say, is folded back into poetry - only in this case that means including considerations of transmission and translation, since these remain, of course, 'after-poems'. It is tempting, if necessarily speculative, to read the history and development of literature into the interregnum between the call of Li-Tai-Po's flute in the eighth century and the response of Bethge's willow-reed in the twentieth. For what the mysterious flute 
ultimately activates is literature itself, the successful transformation of physical conversation (between flute and willow) into metaphysical birdsong (between human and animal). In responding to the song that he hears, Li-Tai-Po composes, in turn, his own new song. It is not just the flute that is mysterious - or 'full of secrets', to translate the German adjective geheimnisvoll literally - but also the willow.

This becomes clearer if we turn for corroboration to a further poem by LiTai-Po, this time translated by Gautier but not by Bethge. 'Chant des oiseaux, le soir' [Birdsong at evening] renders explicit the implicit correlation between birds and lovers, birdsong and speech. A 'maiden' hears the birds singing as she sits embroidering silk, and her thoughts fly to her far-away 'beloved'. The birds, she thinks to herself, can find each other through song; but the tears of the lover cannot recall the object of her desire. Her solution - and the climax of the poem is thus to weave a fragment of poetry into the flowers of his gown: 'Je vais broder une pièce de vers, parmi les fleurs de la robe que je lui destine, et peut-être les caractères lui diront-ils de revenir' (I will weave a line of verse into the flowers of the gown that I am making for him, and perhaps the characters will tell him to come back to me). ${ }^{16}$ The traditional understanding of 'text' as a weave of language (textere) here acquires added resonance through the analogy with birdsong. A circular process of sublimation occurs - poetry becomes birdsong becomes silk becomes poetry - to which one must then add the extra-textual element of translation. As the translator, as the recipient of Li-Tai-Po's poem, Gautier functions as the bird returning the call - or as the lover donning the gown. Secreted across the centuries, the 'characters' call us back to the original text. 
But whose text is this? Does it belong to Li-Tai-Po, to Judith Gautier, to Hans Heilmann, or to Hans Bethge? The complex chain of reception and translation throws up a particularly acute case of authorial anxiety, since the changing cultural contexts exacerbate the traditionally intermediate status of translated texts. If Li-Tai-Po's birds take their Chinese song with them as they fly across the centuries and continents, they are fully Europeanized by the time they reach the West. Indeed, the Hölderlinian cadences of Bethge's final stanza and the family heritage of Gautier's engagement with literature suggest that the poetry of the Tang dynasty is being seen here through the lens of European Romanticism, the inherited idiom both for Gautier (in her case quite literally) and for Bethge. Yet there are also instructive differences between Gautier's French and Bethge's German translations, differences that suggest that the dialogue is as much intraas inter-continental.

For one thing, the aims of their two books are different. Where Bethge offers a selection covering the whole history of Chinese poetry, Gautier concentrates on the classical Tang period, dividing her book thematically (rather than chronologically) into topics such as 'lovers' and 'travellers', 'court' and 'war', 'moon', 'wine', and 'autumn', before concluding with a final, self-reflexive section on 'poets'. It is in this final section that she includes her translation of 'La flûte mystérieuse':

Un jour, par-dessus le feuillage et les fleurs

embaumées, le vent Alors, j'ai coupé une m'apporta le son d'une flûte branche de saule, et j'ai lointaine.

répondu une chanson. 
Depuis, la nuit, lorsque tout

dort, les oiseaux entendent

une conversation dans leur

langage. ${ }^{17}$

One day, above the leaves

and the fragrant flowers,

the wind brought me the

sound of a distant flute.
So I cut off a branch of

willow, and I replied in

song.

Since then, at night, when

everything is asleep, the

birds hear a conversation in

their language.

Gautier's French version of Li-Tai-Po's poem reads very differently to Bethge's German version. The first thing that strikes the reader - before one even considers differences of detail - is the changing feel of the syntax. Gautier is simple where Bethge is syncopated; Gautier follows standard French word order, where Bethge makes use of the greater syntactical flexibility of German to play around with standard word order (thus foregrounding certain key words); Gautier leaves her stanzas unbroken, where Bethge breaks his lines up, in the traditional European manner, with capitals at the start of every strophe. Gautier, one almost wants to say, is 'prosaic', where Bethge self-consciously foregrounds his syntax as 'poetic'.

Further differences are of course also apparent, none more so than the opening move from 'un jour' to 'an einem Abend'. Bethge's shift of the scene from the generic 'one day' to the specific 'one evening' is baffling (although if nothing else it is in keeping with his general attempt to evoke a crepuscular, moonlit mood). The change is all the stranger given the subsequent occurrence at the end of the poem of 'la nuit' as the time when the birds hear their conversation. Gautier sets up a tension, in other words, between the anecdotal, unrepeatable 'un jour' 
and the lyrical, repeatable 'la nuit' - what one might term a chronological (if not a pathetic) fallacy, whereby the transition from day to night marks the transition from the realm of the real to the realm of poetry. In conflating this distinction between (one) day and (at) night into the one, single evening, Bethge misses perhaps one simply has to say mistranslates - the poetic mood that night-time is henceforth meant to evoke. For Bethge, it is since that night - i.e. the one mentioned at the start of the poem - that the birds hear themselves talking; in Gautier, on the other hand, the birds hear themselves at night.

If Bethge mistranslates the timing, he arguably over-translates the place. At night, 'when everything is asleep', writes Gautier; since that evening, 'when the Earth is asleep', responds Bethge. Bethge's rendering gives the scene a metaphysical twist, a kind of planetary plenitude absent from the French but reminiscent of contemporary German poets like Rilke ('Earth, is not this your desire: to arise within us, / invisible?'). ${ }^{18}$ Perhaps the most significant difference, however, lies in the handling of the 'song' itself. Where Gautier's middle stanza is almost matter-of-fact, with the poet's 'chanson' the accusative object to the nominative lyrical 'I', Bethge turns things around dramatically: Gautier's 'j'ai répondu une chanson' (a locution that is itself untranslatable into English, with its transitive sense of 'I replied a song') becomes 'mein Lied flog, Antwort gebend, durch die blühende Nacht'. Bethge heavily stresses the 'Lied', in other words, making it the nominative subject and conferring on it the flowery, effusive action of flying through the blossoming night while 'giving answer'. Metaphysics, once again, trump physics.

While I have concentrated on comparing the translations of 'Die geheimnisvolle Flöte' and 'La flûte mystérieuse' - since they offer obvious 
examples of how Europeans of the nineteenth and twentieth centuries played the 'Chinese flute' - their stylistic tics and lexical choices can also be found in many other translations of Li-Tai-Po's poems by Gautier and Bethge. Time and again the key images of flute, jade, wine, and moon are combined to produce the intoxicated, self-conscious status of 'song' (see poems such as 'Tanz der Götter' [Dance of the Gods] or 'Lied auf dem Flusse' [Song of the River]). Perhaps the most instructive further instance - given that it forms the iconic opening song of Mahler's Lied von der Erde - is to be found in the so-called 'Trinklied vom Jammer der Erde' (Drinking Song of the Sorrow of the Earth). Before we even consider the poem, the title already contains two points of interest: not only does Bethge foreground the status of the poem as a drinking song, but he also once again ratchets up the metaphysical significance, translating Li-Tai-Po's 'Tale of Sorrowful Song' - which the Marquis D'Hervey Saint-Denys renders simply as 'La Chanson du chagrin' - as the 'Drinking Song of the Sorrow of the Earth'. Pokale,

Doch trinkt noch nicht, erst sing ich euch ein Lied! The wine already beckons in its Das Lied vom Kummer soll euch in die Seele golden goblet but drink not yet; first I'll sing you a Auflachend klingen! Wenn der song.

Kummer naht The song of sorrow shall ring into

So stirbt die Freude, der Gesang erstirbt your soul laughingly. When sorrow comes, Wüst liegen die Gemächer meiner so perishes all joy, all singing dies, Seele. blasted lie the chambers of my soul. 
Dark is life, is death.

Compared to the French version - 'Le maître de céans a du vin, mains ne le versez pas encore: / Attendez que je vous aie chanté / La chanson du chagrin. / Quand le chagrin vient, si je cesse de chanter ou de rire, / Personne, dans ce monde, ne connaîtra les sentiments de mon cœur'20 - Bethge composes almost an entirely new poem, which is to say that he domesticates his French source material into a recognisably German idiom. By this, I don't just mean that he makes use of the resources of German syntax to foreground particular aspects of the poem including, for instance, the melancholy transience of time conveyed by the opening opposition of 'schon' and 'doch' (echoed in the closing lines by the despairing repetition of 'jetzt! ... jetzt!') - but also that he tacitly places Li-Tai-Po's eighthcentury Chinese sentiments within a modern German cultural context. Perhaps the most important way that he does this is by coining a refrain that recurs at the end of each of the four stanzas: 'Dunkel ist das Leben, ist der Tod'. For the German reader at the start of the twentieth century, the structure of the phrase evokes Schiller's famous statement in the prologue to Wallensteins Lager (1798): 'Ernst ist das Leben, heiter ist die Kunst' [Life is solemn, art is serene]. ${ }^{21}$ In composing his refrain in this way, Bethge seems to be suggesting that 'death' stands in apposition to 'art', if only in the Romantic, Keatsian sense that death makes art possible. Empty your cup of wine to the lees, Bethge has Li-Tai-Po enjoin the reader in the penultimate line of the poem; enjoy the intoxication of wine and song while you can. There can be no true beauty without decay.

Bethge takes this Romantic position a step further by making sorrow the very death of song, an important change of emphasis given that it alters the French 
translation. 'Quand le chagrin vient, si je cesse de chanter ou de rire, / Personne, dans ce monde, ne connaîtra les sentiments de mon cœur' writes D’Hervey SaintDenys; 'Wenn der Kummer naht, / So stirbt die Freude, der Gesang erstirbt', translates Bethge. The difference is subtle but significant: when sorrow arrives, if I stop singing my sentiments will remain unknown, runs the French version; when sorrow arrives, so all sentiment dies as a consequence, runs the German - and so, crucially, does the song itself. In the French translation, in other words, song represents the procrastination of death; in the German, it functions as its herald.

Such temporal subtleties complicate any straightforward narrative of intercontinental transfer, since they suggest that 'song' - or as we might now say, lyric poetry - requires the echo chamber of ephemerality in order to be heard. Not the immortality of translation, but the mortality of transience gives art its edge. LiTai-Po's 'Trinklied' offers a variation, that is to say, on the emblematic Oriental story of Scheherazade telling stories in order to forestall her own death (it is striking that Mahler simply omits the line 'So stirbt die Freude, der Gesang erstirbt', as though the very existence of his own Lied von der Erde gives the lie to the claim). Translating human song into birdsong emerges, in other words, as a way of transforming physical contingency into metaphysical poetry. Translating classical Chinese literature into European modernism functions in the same manner, foregrounding lyric poetry as a way, in various senses of the term, of keeping time. By singing about art as ephemeral, Bethge paradoxically makes it eternal.

One final poem translated by Bethge via Gautier, this time by Li-Tai-Po's contemporary Thu-Fu, may help summarize the pathos with which he invests his vision of Oriental verse. The poem is entitled simply 'An Li-Tai-Po': 
La poésie est ton langage,

comme le chant est celui des

oiseaux.

Que ce soit à la clarté du soleil ou à

l'ombre du soir,

tu vois la poésie de toutes choses. ${ }^{22}$
Die Poesie ist deine Sprache, Li-Tai-

Po,

So wie das Lied der Vögel ewige

Sprache ist

Im Sonnenlicht und in dem

Schattenland des Abends

Fühlst du die Poesie der Dinge und

nur sie..$^{23}$

When we compare Bethge's version to that of Judith Gautier, two alterations, trivial but telling, immediately jump out at us. By the time that Li-Tai-Po's birdsong, evoked by Thu-Fu and translated by Gautier, reaches the ears of Bethge, it has become emphatically 'eternal' ('ewig'); by the time Li-Tai-Po's 'poetry of all things' arrives, it has become doubly emphatic, since it is now 'only that' ('nur sie'). Such details, alongside the many others that we have adduced, suggest that the task of the translator, in Hans Bethge's view, is ultimately not only to receive, but also to reinforce the source text. Bethge renders classical Chinese into modern German, evoking Hölderlin and Schiller (and imitating George and Rilke) in order to echo Li-Tai-Po's classical call with a modernist response.

What conclusions can we draw from this response? If modernist poetry famously functions through allusion (The Waste Land being, of course, the paradigmatic example), it has been the argument of this essay that it also functions through echo. Echo, by definition, creates sound; as an aural term it foregrounds, by extension, the idea of poetry as music. The modernist model of lyric has the notion of 'echo' at its very centre, not only because it self-consciously looks back 
to ancient poets from a wide range of traditions, but also because it builds reflection on this process of looking back into its very understanding of poetry. The German and French poets who eventually naturalized Chinese 'songs' from the Tang dynasty into 'lyrics' in the European sense derived their impetus from images of the rebirth of prose - songs, birdsong, lyrics, Lieder - into poetry. Translation, understood not only lexically as substituting one set of words for another, but also lyrically as transforming these words into poetic form, emerges from this process as both technique and topic. Between East and West, between the eighth century and the twentieth, the intercontinental lyric constitutes, in short, a kind of 'after-poetry'.

\footnotetext{
NOTES

${ }^{1}$ See Svend Erik Larsen, 'Georg Brandes: The Telescope of Comparative Literature', in The Routledge Companion to World Literature, Edited by Theo d'Haen, David Damrosch, and Djelal Kadir (Abingdon: Routledge, 2012), pp. 21-31.

${ }^{2}$ Susan Stanford Friedman, Planetary Modernisms: Provocations on Modernity across Time (New York: Columbia UP, 2015).

${ }^{3}$ See also Susan Stanford Friedman, 'Cultural Parataxis and Transnational Landscapes of Reading: Toward a Locational Modernist Studies', in Modernism, Edited by Astradur Eysteinsson and Vivian Liska (Amsterdam: John Benjamins, 2007), pp. 35-52.

${ }^{4}$ Stanford Friedman, Planetary Modernisms, p. 278.

${ }^{5}$ See Walter Cohen, A History of European Literature (Oxford: OUP, 2017).

${ }^{6}$ It is often thought, for instance, that the form of the Arabic muwashshah - which classically consists of five stanzas with a running refrain, set to music - played a decisive role in the emergence of the Provencal troubadours (see, among others, Cohen, A History of European Literature, pp. 155-7). Perhaps the most famous example of modern European engagement with the ghazal, meanwhile, is Rilke's sonnet 'Die Gazelle' (1907), in which the poet seems to meditate, through a kind of extended pun, on both the gazelle and the ghazal as forms of grace and beauty. 7 See Jean Paul, Vorschule zur Ästhetik (Hamburg: Meiner, 1990), p. 67.

${ }^{8}$ See Marcel Lepper, Goethes Euphrat: Philologie und Politik im West-Östlichen Divan (Göttingen: Wallstein, 2016), p. 38.

${ }^{9}$ J.W. von Goethe, Werke, ed. Erich Trunz (Hamburg: Deutsche Taschenbuchausgabe, 1998), vol. 2, p. 16.

10 Eric Hayot, 'Chinese Modernism, Mimetic Desire, and European Time', in The Oxford Handbook of Global Modernisms, Edited by Mark Wollaeger and Matt Eatough (Oxford: OUP, 2012), pp. 149170, here p. 149.

11 Ibid., p. 160.

${ }^{12}$ I use the version of his name used by Bethge, since there are numerous variations such as Li Bai or Li Bo. Born in 701 in the Sichuan province of China, Li Tai Po's life alternated between years of nomadic wandering and periods of semi-official service as a court poet to the leaders of the Tang dynasty. After being banished from court in 758, he died in Eastern China in 762.

13 Ezra Pound, The Cantos of Ezra Pound (London: Faber \& Faber, 1964), p. 275.
} 
${ }^{14}$ Hans Bethge, 'Die geheimnisvolle Flöte', in Die chinesische Flöte (Leipzig: Insel, 1922), p. 35.

15 Friedrich Hölderlin, Gedichte, ed. Jochen Schmidt (Leipzig: Insel, 1984), pp. 163-7, here p. 166.

16 Judith Walther, 'Chant des oiseaux, le soir', in Le Livre de jade (Paris: Alphonse Lemerre, 1867), pp. 19-20, here p. 20.

17 Ibid., pp. 149-50.

18 Rainer Maria Rilke, 'Ninth Duino Elegy', Selected Poems tr. Susan Ranson and Marielle Sutherland (Oxford: OUP, 2011), p. 173.

${ }^{19}$ Hans Bethge, 'Trinklied vom Jammer der Erde', in Die chinesische Flöte, pp. 21-22, here p. 21.

20 Marquis d'Hervey Saint-Denys, 'La Chanson du chagrin', in Poésies de l'Époque des Thang (Paris: Amyot, 1862), pp. 70-71, here p. 70.

${ }^{21}$ Friedrich Schiller, Prologue to Wallensteins Lager (Karlsruhe: Bureau der deutschen Klassiker, 1817), vol. 10, p. 8.

22 Judith Walther, 'Louange à Li-Tai-Pé', in Le Livre de jade, pp. 161-2, here p. 161.

${ }^{23}$ Hans Bethge, 'An Li-Tai-Po', in Die chinesische Flöte, p. 42. 